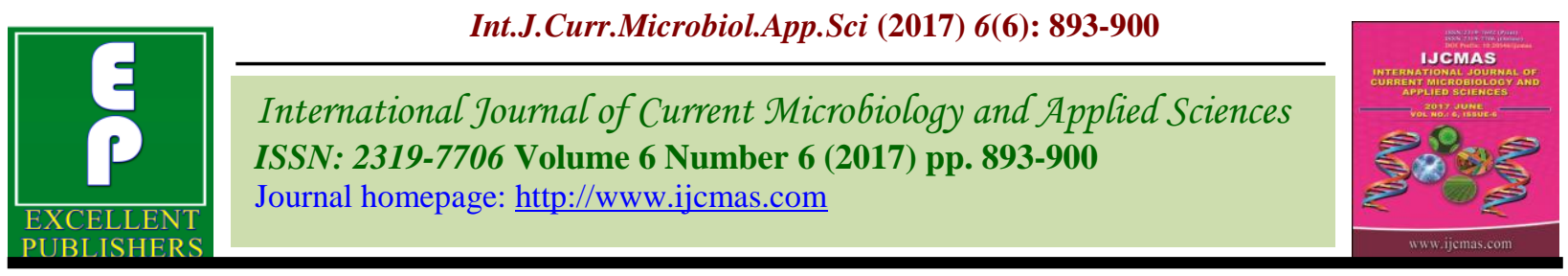

Original Research Article

https://doi.org/10.20546/ijcmas.2017.606.105

\title{
Relative Quantification of Expression of Y-Specific Genes and its Association with Semen Production Traits in Crossbred Jersey Bulls
}

\author{
A. Gopinathan*, S.N. Sivaselvam, J. John Kirubaharan and S.M.K. Karthickeyan \\ Department of Animal Genetics and Breeding, Madras Veterinary College, \\ Chennai - 600 007, India \\ *Corresponding author
}

\section{A B S T R A C T}

The present study was carried out to assess the relative expression of Y- specific genes [Sex determining region on Y-chromosome (SRY), Testis-specific protein

Keywords

\section{Relative}

Expression,

Y-specific genes,

Crossbred Jersey

bulls and qPCR.

Article Info

Accepted:

17 May 2017

Available Online:

10 June 2017 Y-encoded (TSPY) and Ubiquitin specific peptidase 9-Y-linked (USP9Y)] and their association with semen production characters in crossbred Jersey bulls. The blood samples were collected from breeding bulls present in three frozen semen stations in Tamil Nadu. The expressions of Y-specific genes were quantified by quantitative real-time PCR (qPCR) using SYBR green chemistry. The relative standard curve method was used to study the expression of Y-specific genes relative to a reference gene DEAD box polypeptide 3-Y-chromosome (DDX3Y) as control. The increase in expression values of SRY gene was positively and significantly $(\mathrm{P}<0.01)$ correlated with semen volume $(0.688)$ and initial sperm motility (0.739). The decrease in expression value of TSPY gene was associated with increase in semen volume, sperm concentration, initial sperm motility and post-thaw motility over the years, which was significant $(\mathrm{P}<0.01)$ and negatively correlated. The decrease in expression of USP9Y gene was associated with increase in initial sperm motility and post-thaw motility over the years.

\section{Introduction}

Crossing Bos indicus with Bos taurus is a breeding method employed to augment milk production in India through Artificial Insemination programmes. Semen from two exotic breeds namely, Jersey and Holstein Friesian are extensively used for this purpose. But, the karyotypes of Bos indicus and Bos taurus have a high similarity except for the morphology of the Y-chromosome. The genes present in the Y-chromosome plays an essential role in male sex development, spermatogenesis and male fertility. The eutherian Y-chromosome has unique characteristic feature that most part of this chromosome escapes meiotic recombination process with $\mathrm{X}$-chromosome except two regions at the tips of the $\mathrm{X}$ - and $\mathrm{Y}$ chromosomes. This unique recombination pattern of Y-chromosome with its Xcounterpart makes it prone to structural variation (Chang et al., 2013). This kind of structural variations may or may not associate with altered expression of genes present in the Y-chromosome. In India to date, there are 
only few studies on the expression variation of Y-specific genes and their association with semen quality traits in CBJY bulls. Therefore, the present study was focused to investigate variations in expressions of major $\mathrm{Y}$ chromosomal genes such as Sex determining region on Y-chromosome (SRY), Testisspecific protein Y-encoded (TSPY) and Ubiquitin specific peptidase 9-Y-linked (USP9Y) genes using DEAD box polypeptide 3-Y-chromosome (DDX3Y) as a reference gene to find out the relationship with semen production traits of crossbred Jersey (CBJY) bulls.

\section{Materials and Methods}

Blood samples $(5 \mathrm{ml})$ were collected from CBJY (61 samples) bulls of three frozen semen stations in Tamil Nadu, India and stored at $4^{0} \mathrm{C}$ till further processing. Genomic DNA was extracted using standard Phenol-Chloroform extraction procedure (Sambrook et al., 1989). The concentration of DNA was adjusted to $100 \mathrm{ng}$ prior to qPCR. A standard curve was drawn using pooled DNA randomly obtained from CBJY bulls.

\section{Selection of Y-specific and reference genes}

Four Y-specific genes (with an accession number, Gene ID, number of base pairs and number of exons) such as (i) Sex determining region on Y-chromosome (NM_001014385, 280931, 690 bp and 1); (ii) Testis specific protein, Y- encoded (NM_001244608, 281554, 3206 bp and 7); (iii) Ubiquitin specific peptidase 9-Y linked (NM_0011455091, 100271721, 13485 bp and 7) and (iv) DEAD box polypeptide 3-Y chromosome (NM_0011725951, 783057, $10219 \mathrm{bp}$ and 17) were chosen for the present investigation. Different genes like, $\beta$-actin, tubulin and GAPDH genes have been reported to be useful in analysing the relative quantification of gene expression (Imai et al., 2014). However, in the present study DDX3Y gene has been used as a reference gene. This gene has been reported to be a single copy gene in the genome of mammals (Paria et al., 2011). Its utility has also been established in relative quantification in bulls and its expression level has been reported to remain unchanged irrespective of seasons and age (Yue et al., 2014). Hence, selection of DDX3Y gene in the present study is appropriate one to quantify the gene expression.

The pooled DNA was diluted five folds after measuring the initial concentration in a nanodrop. The concentrations in ng variations of four Y-specific gens were quantified by quantitative real-time PCR (qPCR) (Light Cycler® 96 by Roche Real-Time PCR System) using SYBR green chemistry. The primers used for these genes along with annealing temperature and approximate product size are provided in table 1 . The annealing temperatures were arrived by carrying out gradient PCR with Tm values for each primer.

\section{qPCR mixture and reaction conditions}

Each $10 \mu \mathrm{l}$ reaction volume consists of SYBR Green PCR master mix $(5.0 \mu \mathrm{l})$, Primers forward and reverse primers (10 pmoles-1.0 $\mu \mathrm{l}$ each), template DNA (100ng-1.0 $\mu \mathrm{l})$ and PCR graded water $(2.0 \mu \mathrm{l})$. Following were the qPCR protocols adopted for amplifying exonic regions of the $\mathrm{Y}$ - specific genes both for standard and test bull samples.

\section{Expression data analysis}

The relative standard curve method was used to study the expression of $\mathrm{Y}$-specific genes relative to reference gene (control). The following stepwise calculations were applied to find out the copy number variation of $\mathrm{Y}$ specific genes. With the Ct values, using MS Excel programme, slope, intercept and r2 values were estimated. 
The $\mathrm{Ct}$ values were transformed into "Sample ng" by applying the following formula

Sample $(\mathrm{ng})=10(\mathrm{Ct}$ sample-intercept/slope $)$

The sample ng values were normalized with reference gene control by applying the formula

Sample sample (ng) reference gene(ng)

The expression percentage is obtained by the following formula sample (ng) - control (ng)

Ratio expression $=$

control (ng)

The age group classification of CBJY bulls was arrived by taking into consideration of minimum and maximum age present in the data such as 1.5 to $3.0,3.1$ to $4.5,4.6$ to 6.0 , 6.1 to 7.5 and more than $>7.5$ years.

\section{Association between gene expression and semen production traits}

The basic statistics like mean and standard error were computed for semen volume ( $\mathrm{ml})$, sperm concentration (millions per $\mathrm{ml}$ ), mass activity (0 to 5 scales), initial sperm motility (in per cent), post-thaw motility (in per cent) and number of doses per ejaculates for different age groups of CBJY bulls. Correlation between the fold increase in DNA concentration (in ng) and the semen production parameters were done as per Snedecor and Cochran (1987) to find out the association. The significance for correlation results was confirmed by using correlation table (r).

\section{Results and Discussion}

The amplification, melting and standard curves drawn with ct value and $\log 10$ concentration of DNA (ng per reaction) with slope, intercept and r2 values for SRY, TSPY and USP9Y genes are presented in figure 1.

The means for the semen production traits such as semen volume, sperm concentration, initial sperm motility and post-thaw motility; expression values (concentration in $\mathrm{ng}$ ) of SRY, TSPY and USP9Y genes for different age groups of CBJY bull and phenotypic correlations between expression values of SRY TSPY and USP9Y genes and semen production traits are given in table 2 .

\section{Sex determining region on Y-chromosome}

At 1.5 to 3.0 years of age, the expression values as concentration of SRY gene was $343.91 \mathrm{ng}$, after which it decreased (280.30 ng) at 4.6 to 6.0 years and increased to the maximum (455.09 ng) during 6.1 to 7.5 years of age. The increase in expression values of SRY gene was positively and significantly $(\mathrm{P}<0.01)$ correlated with semen volume $(0.688)$ and initial sperm motility (0.739).

\section{Testis specific protein on Y-encoded}

The expression values as concentration of TSPY gene was $25.19 \mathrm{ng}$ for 1.5 to 3.0 years of age and it decreased (16.49 ng) up to 6.1 to 7.5 years of age in CBJY bulls.

The decrease in expression value of TSPY gene was associated with increase in semen volume, sperm concentration, initial sperm motility and post-thaw motility over the years, which was significant $(\mathrm{P}<0.01)$ and negatively correlated.

\section{Ubiquitin specific peptidase 9-Y-linked}

The expression values as concentration of USP9Y gene was $52.09 \mathrm{ng}$ for 1.5 to 3.0 years of age and it decreased (28.12 ng) up to 6.1 to 7.5 years of age. 
The decrease in expression of USP9Y gene was associated with increase in initial sperm motility and post-thaw motility over the years.

\section{Sex determining region on Y-chromosome}

The SRY gene has been reported to play a role in the male pathway of gonad development (Polanco and Koopman, 2007). On perusal of literature, to the best our knowledge, we could not identify literature dealing with correlation of expression of SRY gene with semen production parameters. Expression analysis of SRY gene was carried out for embryo sexing and sex determination pathways. However, significant copy number variations of SRY gene in crossbred bulls have been reported by Mukherjee et al., 2013; while no such variation was found by Verkarr

et al., (2003). Hence, it could be hypothesized from the available literatures that an increased expression of SRY gene could result in a cascade of molecular reorganization in the nascent testis and that would initiate the sertoli cell synthesis during embryonic stages, which is essential for giving energy to sperms as reflected upon the initial sperm motility.

\section{Testis specific protein on Y-encoded}

The TSPY gene was reported to be involved in early spermatogenesis process in mammals (Vogel and Schmidke, 1998). The results of the expression analysis were in agreement with earlier reports of Hamilton et al., (2012) in purebred HF bulls. However, significant differences in copy number variation of TSPY gene were observed between crossbred and indicine bulls (Mukherjee et al., 2013). In human, there was an ambiguity over the function of the TSPY gene reported by Giachini et al., (2012), Nickkbolgh et al., (2010) and Krause et al., (2010). Hence, the TSPY gene expression is more during early spermatogenesis process and as the spermatogenesis continued for several years after sexual maturity; its gene expression is reduced in subsequent ages.

Table.1 Primers used for quantitative real time PCR

\begin{tabular}{|c|c|c|c|}
\hline Genes & Primer sequence $\left(5^{\prime} 3^{\prime}\right)$ & $\begin{array}{l}\text { Annealing } \\
\text { temperature } \\
\left({ }^{0} \mathrm{C}\right)\end{array}$ & $\begin{array}{l}\text { Fragments } \\
\text { size (bp) }\end{array}$ \\
\hline \multirow{2}{*}{$S R Y$} & $\begin{array}{l}\text { Forward : CTA GAG AAT CCC AAA ATG AAA } \\
\text { AAC TC }\end{array}$ & \multirow{2}{*}{61} & \multirow{2}{*}{150} \\
\hline & $\begin{array}{l}\text { Reverse : ATA TTT ATA GCC CGG GTA TTT GTC } \\
\text { TC }\end{array}$ & & \\
\hline \multirow{2}{*}{$T S P Y$} & Forward : AGT TGT GAG CCC AGT TGT CA & \multirow{2}{*}{61} & \multirow{2}{*}{148} \\
\hline & Reverse : CAC CTC CTC CAC GAT GTC TT & & \\
\hline \multirow{2}{*}{ USP9Y } & $\begin{array}{l}\text { Forward : GTA CAC AGT GGT CAA GCA AGT } \\
\text { GGT A }\end{array}$ & \multirow{2}{*}{61} & \multirow{2}{*}{178} \\
\hline & $\begin{array}{l}\text { Reverse : CTT CTC CCA TGT ACT CTC CAC CAA } \\
\text { A }\end{array}$ & & \\
\hline \multirow[b]{2}{*}{$D D X 3 Y$} & $\begin{array}{l}\text { Forward : GTT AGA TTT CTG CAA ATA CTT GGT } \\
\text { GTT }\end{array}$ & \multirow[b]{2}{*}{61} & \multirow{2}{*}{101} \\
\hline & $\begin{array}{l}\text { Reverse : GCA TAG TGT CTT GTT CAA TTA TAC } \\
\text { GAC }\end{array}$ & & \\
\hline
\end{tabular}


Table.2 Mean \pm S.E. of expression of Y-specific genes and semen production traits with their Correlation co-efficient in CBJY bulls

\begin{tabular}{|c|c|c|c|c|c|c|c|c|}
\hline \multirow[t]{2}{*}{$\begin{array}{l}\text { Age group } \\
\text { (in years) }\end{array}$} & \multirow{2}{*}{$\begin{array}{c}\text { Number } \\
\text { of } \\
\text { bulls }\end{array}$} & \multicolumn{3}{|c|}{$\begin{array}{c}\text { Expression values as } \\
\text { concentration (in ng) of } \\
\text { Y-specific genes }\end{array}$} & \multirow[t]{2}{*}{$\begin{array}{c}\text { Semen } \\
\text { volume }(\mathbf{m l})\end{array}$} & \multirow{2}{*}{$\begin{array}{l}\text { Sperm } \\
\text { concentration } \\
\text { (millions per } \\
\text { ml) }\end{array}$} & \multirow{2}{*}{$\begin{array}{c}\text { Initial } \\
\text { sperm } \\
\text { motility } \\
\text { (in per cent) }\end{array}$} & \multirow{2}{*}{$\begin{array}{c}\text { Post-thaw } \\
\text { motility } \\
\text { (in per cent) }\end{array}$} \\
\hline & & SRY & TSPY & USP9Y & & & & \\
\hline 1.5 to 3.0 & 20 & $\begin{array}{c}343.91 \\
\pm \\
117.38 \\
\end{array}$ & $\begin{array}{l}25.19 \\
\pm 4.26\end{array}$ & $\begin{array}{c}52.09 \pm \\
9.49\end{array}$ & $3.36^{\mathrm{bc}} \pm 0.15$ & $1254.19 \pm 92.93$ & $58.57 \pm 4.34$ & $50.99 \pm 0.42$ \\
\hline 3.1 to 4.5 & 10 & $\begin{array}{r}296.39 \\
\pm 80.25 \\
\end{array}$ & $\begin{array}{r}30.23 \\
\pm 7.64 \\
\end{array}$ & $\begin{array}{c}45.98 \pm \\
10.72 \\
\end{array}$ & $3.46^{\mathrm{bc}} \pm 0.25$ & $\begin{array}{l}1151.45 \pm \\
108.75 \\
\end{array}$ & $56.64 \pm 5.50$ & $50.27 \pm 1.74$ \\
\hline 4.6 to 6.0 & 14 & $\begin{array}{r}280.30 \\
\pm 48.40 \\
\end{array}$ & $\begin{array}{r}23.16 \\
\pm 5.35 \\
\end{array}$ & $\begin{array}{c}37.92 \pm \\
5.80\end{array}$ & $3.71^{\mathrm{bc}} \pm 0.15$ & $1076.38 \pm 54.93$ & $64.75 \pm 4.49$ & $51.06 \pm 0.60$ \\
\hline 6.1 to 7.5 & 12 & $\begin{array}{r}455.09 \\
\pm 62.43 \\
\end{array}$ & $\begin{array}{r}16.49 \\
\pm 4.63 \\
\end{array}$ & $\begin{array}{c}28.12 \pm \\
5.02 \\
\end{array}$ & $4.38^{\mathrm{b}} \pm 0.31$ & $1193.45 \pm 69.53$ & $73.27 \pm 1.03$ & $52.45 \pm 1.34$ \\
\hline$>7.5$ & 5 & $\begin{array}{l}405.06 \\
\pm 58.00\end{array}$ & $\begin{array}{r}20.10 \\
\pm 6.90\end{array}$ & $\begin{array}{c}54.31 \pm \\
10.30\end{array}$ & $5.27^{\mathrm{a}} \pm 0.42$ & $986.83 \pm 86.73$ & $65.17 \pm 4.20$ & $50.00 \pm 0.44$ \\
\hline \multicolumn{5}{|c|}{$\begin{array}{l}\text { Phenotypic correlation between expression values (in } \\
\text { ng) of } S R Y \text { gene and semen production traits }\end{array}$} & $0.69 * *$ & $0.02^{\mathrm{NS}}$ & $0.74 * *$ & $-0.09^{\mathrm{NS}}$ \\
\hline \multicolumn{5}{|c|}{$\begin{array}{l}\text { Phenotypic correlation between expression values (in } \\
\text { ng) of TSPY gene and semen production traits }\end{array}$} & $-0.84 * *$ & $-0.35^{* *}$ & $-0.77 * *$ & $-0.34 * *$ \\
\hline \multicolumn{5}{|c|}{$\begin{array}{l}\text { Phenotypic correlation between expression values (in } \\
\text { ng) of } U S P 9 Y \text { gene and semen production traits }\end{array}$} & $-0.06^{\mathrm{NS}}$ & $-0.19^{\mathrm{NS}}$ & $-0.45^{* *}$ & $-0.88 * *$ \\
\hline
\end{tabular}


Fig.1 Expression of SRY (a, b and c), TSPY $\left(\mathrm{a}_{1}, \mathrm{~b}_{1}\right.$ and $\left.\mathrm{c}_{1}\right)$ and $\operatorname{USP} 9 Y\left(\mathrm{a}_{2}, \mathrm{~b}_{2}\right.$ and $\left.\mathrm{c}_{2}\right)$ genes

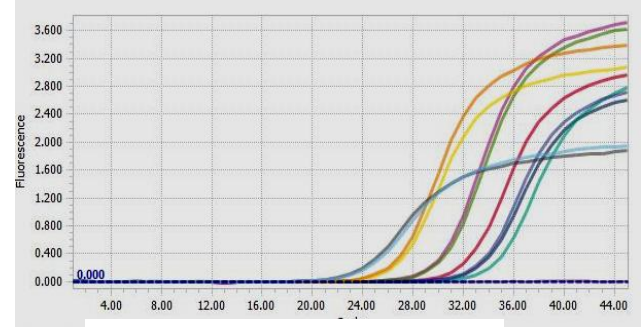

(a) Amplification

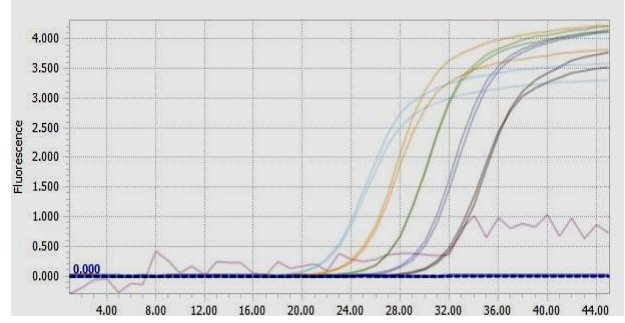

( $\left.a_{1}\right)$ Amplification

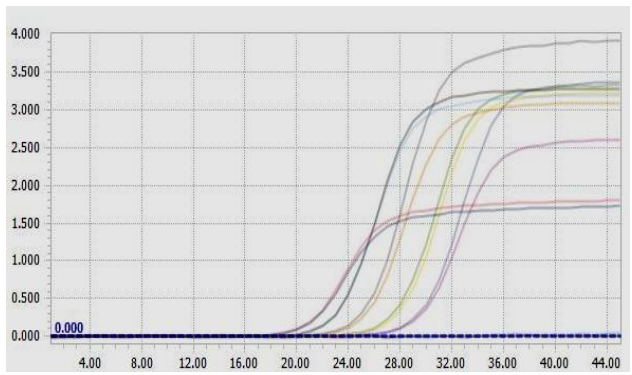

$\left(\mathrm{a}_{2}\right)$ Amplification

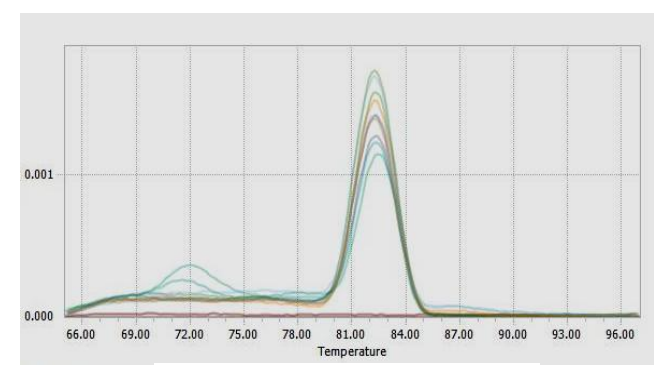

(b) Melting curve

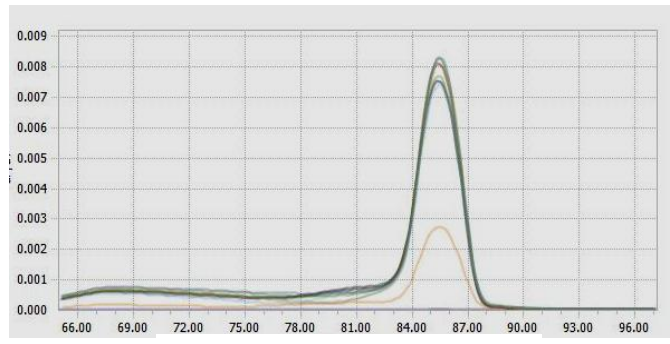

$\left(b_{1}\right)$ Melting curve

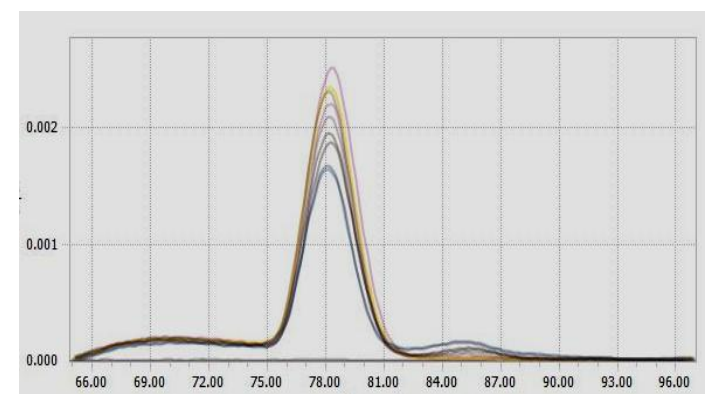

$\left(b_{2}\right)$ Melting curve

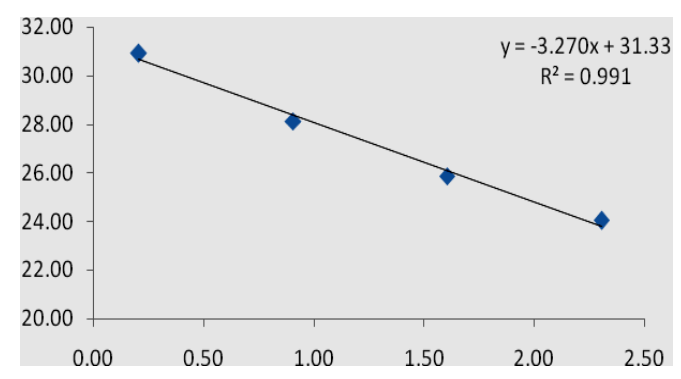

(c) Standard curve

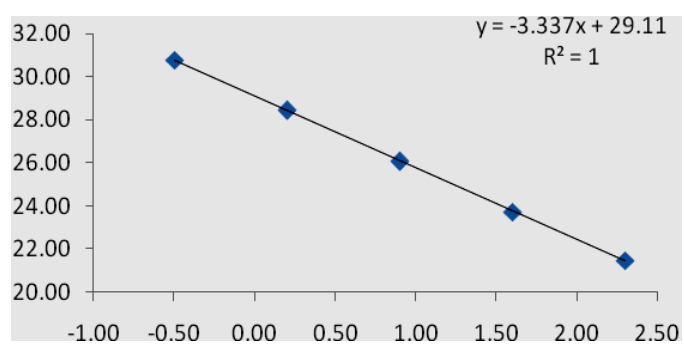

$\left(\mathrm{c}_{1}\right)$ Standard curve

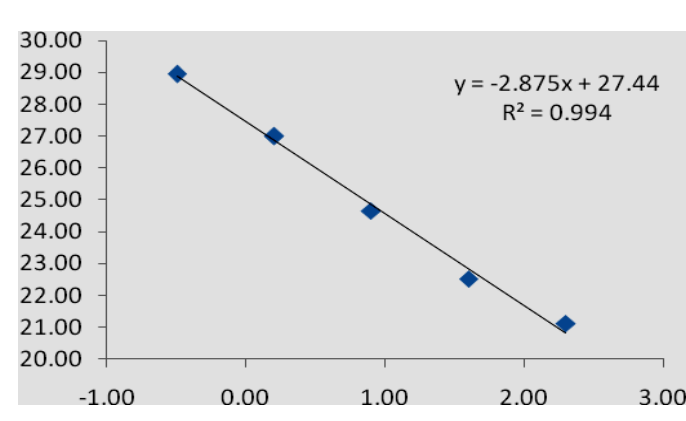

$\left(\mathrm{c}_{2}\right)$ Standard curve 


\section{qPCR mixture and reaction conditions}

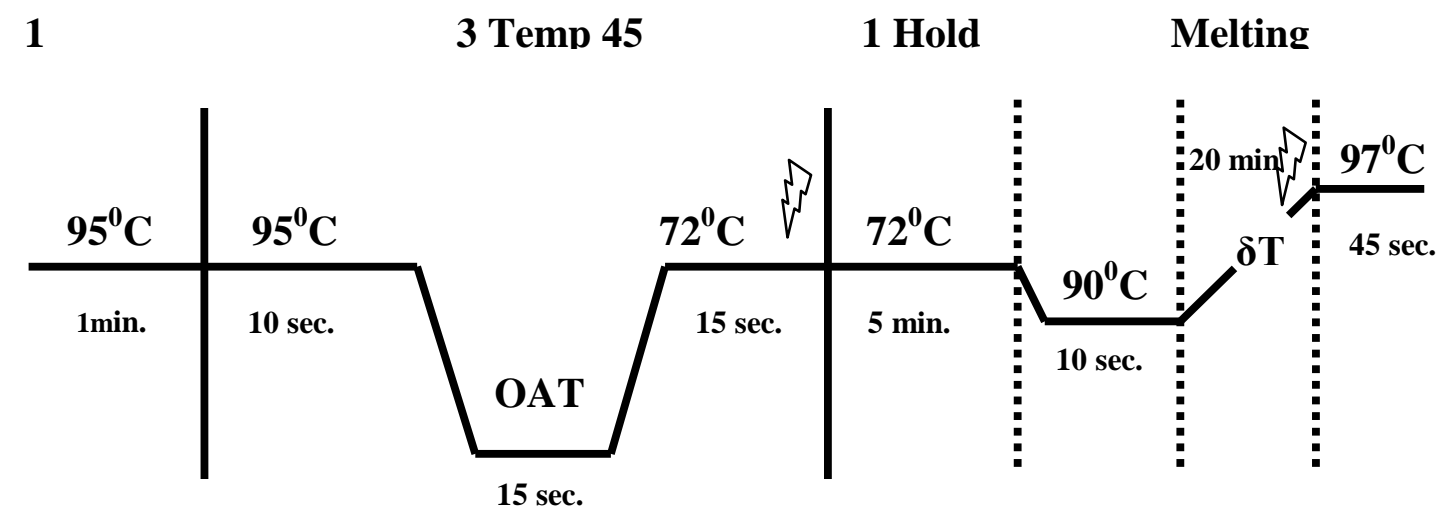

\section{Ubiquitin specific peptidase 9-Y-linked}

The decreased expression of USP9Y gene was in general, negatively correlated with semen volume, sperm concentration, initial sperm motility and post-thaw motility, which was not in agreement with earlier reports of Paria et al., (2011) and Mukherjee et al., (2013), who postulated that USP9Y gene was a single copy gene in cattle. In human, Vineeth and Malini (2011) observed that USP9Y gene could not be considered as a major gene involved in spermatogenesis. But, Bonfiglio et al., (2012) reported that USP9Y gene was more likely a regulatory gene that improves efficiency rather than providing an essential function during spermatogenesis in mammals. Therefore, the variation in expression of USP9Y gene, as related to the age of the breeding bulls, which influences the functional characteristics of spermatozoa.

To conclude that the variation in the expression of Y-specific SRY, TSPY and USP9Y genes in semen production of CBJY bulls revealed positive and significant $(\mathrm{P}<0.01)$ correlation of SRY gene with semen volume and initial sperm motility; and negative and significant $(\mathrm{P}<0.01)$ correlations of TSPY gene with semen volume, sperm concentration, initial sperm motility and postthaw motility. But, negative correlations of USP9Y gene with semen volume, sperm concentration, initial sperm motility and postthaw motility were reported.

\section{Acknowledgement}

The authors are thankful to the Tamil Nadu Veterinary and Animal Sciences University for the financial assistance provided to the Department of Animal Genetics and Breeding, Madras Veterinary College, Chennai to carry out this research.

\section{References}

Bonfiglio, S., A.D. Gaetano, K. Tesfaye, V. Grugni, O. Semino and Ferretti, L. 2012. A novel USP9Y gene polymorphism allowing a rapid and unambiguous classification of Bos taurus Y-chromosomes into haplogroups. Anim. Genet., 43: 611613.

Chang, T.C., Y. Yang, E.F. Retzel and Liu, W.S. 2013. Male specific region of the bovine Y-chromosome is gene rich with a transcriptomic activity in testis development. Proceedings of the National Academy of Sciences of the United States of America, 10: 1237312378.

Giachini, C., F. Nuti, D.J. Turner, I. Laface, Y. Xue, F. Daguin, G. Forti, C.T. Smith and Krausz, C. 2012. TSPY1 copy number variation influences 
spermatogenesis and shows differences among Y lineages. J. Clin. Endocrinol. Metabolism, 94: 4016-4022.

Hamilton, C.K., A.R.V. Gomez, L.A. Favetta, P. Blondin and King, W.A. 2012. Testis-specific protein Y-encoded copy number is correlated to its expression and the field fertility of Canadian Holstein bulls. Sexual Dev., 6: 231-239. Imai, T., B.E. Ubi, T. Saito and Moriguchi, T. 2014. Evaluation of reference genes for accurate normalization of gene expression for real time-quantitative PCR in Pyrus pyrifolia using different tissue samples and seasonal conditions. PLOS ONE, 9: e86492.

Krausz, C., C. Giachini and Forti, G. 2010. TSPY and male infertility. Genes, 1: 309-316.

Mukherjee, A., G. Dass, G.J. Mohanarao, M. Gohain, B. Brahma, T.K. Datta and De, S. 2013. Absolute copy number differences of Y-chromosomal genes between crossbred (Bos taurus $x$ Bos indicus) and Indicine bulls. J. Anim. Sci. Biotechnol., 4:15-18.

Nickkbolgh, B., M.J. Noordam, S.E. Hovingh, M.M.V. Pelt, F.V.D. Veen and Repping, S. 2010. Y-chromosome TSPY copy numbers and semen quality. Fertility and Sterility, 94: 1744-1747.

Paria, N., T. Raudsepp, A.J.P. Wilkerson, P. C.M. O'Brien, M.A.F. Smith, C.C. Love, C. Arnold, P. Rakestraw, W. J. Murphy and B.P. Chowdhary, 2011. A gene catalogue of the euchromatic male-specific region of the horse $\mathrm{Y}$ chromosome: comparison with human and other mammals. PLoS One, 6: 21374.

Polanco, J.C., and Koopman, P. 2007. Sry and the hesitant beginnings of male development. Develop. Biol., 302: 1324.

Sambrook, J., E.F. Fritsch and Maniatis, T. 1989. Molecular Cloning: A Laboratory Manual, 2nd edn., Cold spring harbour, Cold Spring Laboratory Press. NY,

Snedecor, G.W., and Cochran, W.G. 1987. Statistical Methods, 5th edn., Iowa State University Press, Ames, Iowa. pp. $\mathrm{x} x+503$.

Verkaar, E.L., I.J. Nijman, M. Beeke, E. Hanekamp and Lenstra, J.A. 2003. Maternal and paternal lineages in crossbreeding bovine species. Has wisent a hybrid origin? Mol. Biol. Evol., 21: 1165-1170.

Vineeth, V.S., and Malini, S.S. 2011. A journey on Y-chromosome genes and male infertility. Int. J. Human Genet., 11: 203-215.

Vogel, T., and Schmidtke, J. 1998. Structure and function of TSPY, the Ychromosome gene coding for the "testisspecific protein". Cytogenet. Cell Genet., 80: 209-213.

Yue, X.P., C. Dechow, T.C. Chang, J.M. Dejarnette, C.E. Marahall, C.Z. Lei and Liu, W.S. 2014. Copy number variations of the extensively amplified Y-linked genes, HSFY and ZNF280BY in cattle and their association with male reproductive traits in Holstein bulls. BMC Genomics, 15: 11.

\section{How to cite this article:}

Gopinathan A., S.N. Sivaselvam, J. John Kirubaharan and Karthickeyan S.M.K. 2017. Relative Quantification of Expression of Y-Specific Genes and Its Association with Semen Production Traits in Crossbred Jersey Bulls. Int.J.Curr.Microbiol.App.Sci. 6(6): 893-900. doi: https://doi.org/10.20546/ijcmas.2017.606.105 